Jarosław Superson SAC

\title{
Sesja naukowa Sacrosanctum Concilium: punti di arrivo e di partenza (Rzym, 6 grudnia 2007)
}

W Papieskim Instytucie Liturgicznym św. Anzelma w Rzymie 6 grudnia 2007 roku o godz. $16^{00}$ rozpoczęła się sesja naukowa pt. Sacrosanctum Concilium: punti di arrivo e di partenza (Sacrosanctum Concilium: punkt dojścia $i$ wyjścia). Sesja ta wpisuje się w cykl naukowych spotkań, które Instytut wraz z centrum Akcji liturgicznej i Stowarzyszeniem Profesorów i Miłośników Liturgii organizuje w grudniu już od kilku lat, a które mają za zadanie przybliżać i badać dziedzictwo zapisane w Konstytucji o liturgii świętej Soboru Watykańskiego II. Grudniowy termin tych spotkań został wybrany dlatego, że ojcowie soborowi podpisali tę konstytucję 4 grudnia 1963 roku.

Modlitwę rozpoczynającą sesję poprowadził abp Piero Marini, przewodniczący Papieskiego Komitetu ds. Międzynarodowych Kongresów Eucharystycznych.

Dyrektor Papieskiego Instytutu Liturgicznego o. Juan Javier Flores OSB przywitał wszystkich zebranych w auli gości, profesorów i studentów, wśród których był także obecny mistrz ceremonii Papieskiego Urzędu ds. Celebracji Liturgicznych mons. Guido Marini.

1. Pierwszy referat przedstawił prof. Papieskiego Instytutu Liturgicznego o. Matias Augé. Nosił on tytuł Il movimento liturgico: alla ricerca della fondazione spirituale della liturgia (Ruch liturgiczny: w poszukiwaniu fundamentu duchowości liturgicznej).

Prelegent zauważył, że ruch liturgiczny ma swoje korzenie w epoce oświecenia, dziedzictwie benedyktyńskiego opactwa z Solesmes, magisterium papieża Piusa XII i dokumentach Soboru Watykańskiego II. Autor zaakcentował te elementy (etapy) historii Kościoła, które wpłynęły na formowanie się myśli późniejszego dziedzictwa ruchu liturgicznego, ciągle żyjącego w refleksji i dążeniach Kościoła.

Związek między liturgią a duchowością zauważył i podkreślał Prosper Guéranger, który cykl roku liturgicznego widział jako pomoc potrzebną w formowaniu się osobistej modlitwy wiernych. Papież Pius X w doku- 
mencie Tra le sollecitudini mówił o uczestnictwie w liturgii. Właśnie temat uczestnictwa będzie istotnym elementem myśli Lamberta Beauduina. Odtąd duchowość Kościoła to nie praktyki pobożności, ale liturgia, która ma tworzyć fundament duchowości osobistej. Życie duchowe według Maurice'a Festugière’a jest w liturgii, tam jest jej źródło. Stąd wysuwa on wniosek, że kult mówi o duchowości Kościoła. Natomiast inny protagonista ruchu liturgicznego L. Beauduin, który porównuje liturgię i duchowość Kościoła, podkreśla, że autentyczna pobożność Kościoła jest liturgiczna. On także zauważył, że Kościół musi przebyć długą drogę, aby to zrozumieć. Zjednoczenie wiernych i ich uczestnictwo w Kościele dokonuje się przez przyjęcie duchowości liturgicznej.

Drugi etap to okres międzywojenny, działalność papieży Piusa XI i Piusa XII. Wprowadzono wówczas uroczystość Chrystusa Króla. Pius XI, proklamując encyklikę Quas primas, zauważa, że liturgia ma w sobie aspekt pedagogiczny. Natomiast Pius XII w encyklice Mystici Corporis docenia dorobek ruchu liturgicznego, ale i wskazuje jego nadużycia. Natomiast inna jego encyklika Mediator Dei prezentuje wymiar chrystologiczny i eklezjalny liturgii. Ten dokument magisterium Kościoła widzi w liturgii pomoc w odrodzeniu życia Kościoła i odnowieniu kapłaństwa. Mediator Dei korzysta z dorobku Romano Guardiniego i Odo Casela, którzy liturgię widzieli jako działanie całego Kościoła powołanego przez Jezusa Chrystusa. Oni także podkreślają, że nie można liturgii oderwać od duchowości. Duchowość liturgiczna daje wiernym możliwość życia Chrystusem, który żyje w Kościele. Odo Casel podkreśla, że liturgia jest w sercu zbawienia i życia wiernych. Natomiast kolejny protagonista ruchu liturgicznego Pius Parsch zwraca uwagę, że liturgia sprawowana podczas roku kościelnego daje możliwość uczestnictwa w życiu Chrystusa.

Ważnym elementem propagowania myśli ruchu liturgicznego było spotkanie w Asyżu w 1956 roku. Uczestnicy spotkania ruch liturgiczny i jego wezwanie do aktywnego uczestnictwa w liturgii widzieli jako przejście Ducha Świętego przez Kościół. Ruch liturgiczny sprawił, że dziedzictwo ukrytego skarbu - liturgii na nowo zostało odkryte. Sam proces odkrywania dokonuje się stopniowo.

2. Drugi referat zaprezentował nowo zatrudniony wykładowca Papieskiego Instytutu Liturgicznego o. Giuseppe Midili OCarm. Nosił on tytuł La Sacrosanctum Concilium: pietra miliare della riforma liturgica e ponte tra passato e futuro (Konstytucja o Liturgii świętej: kamień milowy reformy liturgicznej $i$ most między przeszłościa a przyszłościa).

We wstępie autor zaprezentował myśli z dokumentu papieskiego Vicesimus quintus annus, w którym papież Jan Paweł II dokonał syntezy dzie- 
dzictwa Sacrosanctum Concilium. Dla papieża soborowa konstytucja jest kamieniem milowym w nauczaniu Kościoła o liturgii, a zarazem punktem odniesienia w badaniach i dyskusjach na temat liturgii w trzecim tysiącleciu Kościoła. Taka świadomość liturgii według prelegenta jest kontynuacją postulatu R. Guardiniego, który mówiąc o formacji liturgicznej, widział ją jako najważniejsze zadanie Kościoła.

Autor przypomniał, że motywem ogłoszenia przez Ojców Soboru Watykańskiego II Konstytucji o liturgii świętej była ich troska „o odnowienie i rozwój liturgii” w Kościele. To ona pomaga w nieustannym pogłębianiu chrześcijańskiego życia wiernych (por. konst. Sacrosanctum Concilium, 1). Proces odnowy liturgii ma pomóc w otrzymywaniu łask podczas sprawowania świętych obrzędów (por. konst. Sacrosanctum Concilium, 21). Pismo Święte, które „ma doniosłe znaczenie w sprawowaniu liturgii” (konst. Sacrosanctum Concilium, 24) jest dorodnym owocem reformy soborowej i kryterium normatywnym dla liturgii (por. konst. Sacrosanctum Concilium, 24). Natomiast sprawowane obrzędy mają uwydatnić wewnętrzny związek ze słowem. Zarazem sobór postuluje szlachetną prostotę obrzędów dostosowanych do pojętności wiernych (por. konst. Sacrosanctum Concilium, 34).

Zdaniem prelegenta z lektury Sacrosanctum Concilium i Lumen gentium wyłania się relacja między lex credendi i lex orandi, które nawzajem ofiarowują swoje dziedzictwo.

Konstatując, że Sacrosanctum Concilium jest kamieniem milowym w rozumieniu, czym jest liturgia w Kościele i jej reforma, o. Giuseppe Midili zauważa, że ojcowie soborowi w tymże dokumencie podali także niektóre zasady, którymi należy się kierować, ustanawiając „praktyczne normy odnowy i rozwoju liturgii” (konst. Sacrosanctum Concilium, 3). Reforma liturgii, zdaniem referenta, ma gwarantować takie wykorzystanie wymienionych w Konstytucji o liturgii świętej norm odnowy i rozwoju, aby hic et nunc w historii celebrowano misterium Chrystusa. Wówczas reforma wpisuje się w dzieje ludzkości; staje się fundamentalnym etapem całej Tradycji. Episkopaty poszczególnych narodów są podmiotem, a zarazem organem gwarancji katolickości, również na polu reformy liturgii (por. konst. Sacrosanctum Concilium, 22). Mają one dołożyć wszelkich starań, aby wierni owocnie uczestniczyli w jej sprawowaniu jako lud Boży. Język i przestrzeń mają pomagać w takim uczestnictwie. Prelegent zauważył także, że oglądać (widzieć) to nie jedyny kod komunikacyjny. Komunikujemy także językiem symbolicznym, nie mówiąc i nie widząc. Referent jest zdania, że te kody komunikacyjne przekazują najwięcej informacji.

Prelegent poruszył także zagadnienie praktyki sprawowania sakramentów inicjacji oddzielnie. Ma to miejsce już od dłuższego czasu w Kościele. 
Jest to nieraz powodem wielu negatywnych wypowiedzi innych Kościołów pod adresem Kościoła rzymskokatolickiego. Chociaż Sacrosanctum Conciclium nie poświęca zbytnio uwagi, jak należy sprawować sakramenty inicjacji, to zdaniem prelegenta jest to nadal kwestia otwarta w teologicznej debacie i praktyce pastoralnej.

W zakończeniu autor podkreślił potrzebę uczenia, edukowania wiernych do sprawowania aktu kultu, który dokonywałby się w przestrzeni i duchu Kościoła. Taki kult daje gwarancję ciągłego procesu uczenia się.

3. Trzecim prelegentem był mons. Giuseppe Busani z Piacenzy, który miał omówić temat La riforma liturgica e il genuino spirito della liturgia (Reforma liturgiczna $i$ autentyczny duch liturgii). Niestety temat ten nie został zaprezentowany. Prelegent mówił natomiast o kulturze i rycie. Zauważył, że reforma liturgiczna doceniła walor kulturowy społeczeństwa. Kult „czyni” kulturę, ale nie zawsze kultura pomaga zrozumieć akt kultu. Mszały rzymskokatolickie z 1962 i 1970 roku propagują temat uczestnictwa. Nowością mszału z 1970 roku jest postulat - pierwsza próba, aby wszyscy wierni aktywnie uczestniczyli w obrzędzie. Autor także zauważył, że kultura czyni wszystko widzialnym i dotykalnym, natomiast nie wkracza w misterium objawienia. W kulturze objawia się życie, które nie umiera.

Sens celebrowania nie tyle zawiera się w odpowiedzi na pytanie, co sprawujemy, ile raczej co się dokonuje, wydarza. Nie jakość sprawowanego rytu, ale akt modlitewny - prezentowana modlitwa daje możliwość komunikacji. Tradycyjne ujęcie podkreślało obrzęd i jego wymogi, dzisiaj coraz częściej akcent pada na odpowiedź na pytanie, jak się wyrażać podczas sprawowanego obrzędu.

Prelegent przytoczył punkt 30 Sacrosanctum Concilium, w którym jest mowa o elementach wzmagających czynne uczestnictwo wiernych: są to aklamacje, odpowiedzi, psalmy, antyfony, pieśni, gesty i postawy ciała. Ale dodaje mons. Giuseppe Busani, że uczestnictwo człowieka wzmaga się dzięki głosowi, milczeniu, zapachowi itd. To wszystko ma wyrazić się jako efekt bezpośredni podczas obrzędu, a nie po jego zakończeniu.

Podczas obrzędu, dzięki swej wrażliwości na wyżej zaprezentowane elementy, wierny ma dotrzeć do sensu sprawowanej akcji. Stąd nie można mówić o kodzie estetycznym wpisanym w obrzęd, który by nie współgrał ze zmysłami człowieka, dzięki którym wchodzi on w uczestnictwo. Rytualność nade wszystko ma dać odczuć sprawowaną tajemnicę. Stąd obrzęd aktywuje potrzebne kody komunikacyjne i je zawiesza; zaprasza do dialogu i przerywa go milczeniem.

Kończąc sesję naukową, postawiono kilka pytań i dodano kilka dopowiedzeń. 
Mons. prof. Crispino Valenziano z Papieskiego Instytutu Liturgicznego zapytał o obrzędowość przyszłości. Stwierdził, że już dość mówienia o czynnym uczestnictwie, należy podkreślać aktywność uczestnictwa (l'attività partecipativa, a nie actuosa participatio).

Abp Piero Marini zauważył, że w momencie kiedy obrzęd został promulgowany, już jest martwy. A przecież celebracja ma być żywa. Po Soborze Watykańskim II celebrowanie stało się trudniejsze niż przed soborem. Kultura współczesna tworzy klimat utrudniający przeżywanie liturgii.

Prof. Silvano Maggiani OSM z Papieskiego Instytutu Liturgicznego postawił pytanie o to, co przeszkadza w rozumieniu celebrowanej istoty, która wyraża się przez formę. Profesor odwołał się do ostatniego VIII Międzynarodowego Kongresu Liturgicznego mającego miejsce w Rzymie (16-18 maja 2007) i zatytułowanego „Per ritus et preces”: sakramentalność liturgii i podkreślił, że sprawowana istota „przechodzi” przez formę i objawia się w formie. Do tego sformułowania dodaje on zapytanie: co w tym procesie wiedzie prym - słowo czy w znak?

Prof. Ildebrando Scicolone OSB z Papieskiego Instytutu Liturgicznego odwołał się do punktu 16 Konstytucji o liturgii świętej i skonstatował, że chociaż sobór zalicza naukę świętej liturgii do przedmiotów koniecznych i ważniejszych, to mimo to dzisiaj celebransi nie są przygotowani do jej sprawowania.

Pewien student z Papieskiego Instytutu Liturgicznego zauważył przełom, jaki dokonał się w myśli Kościoła. Jeszcze nie tak dawno magisterium Kościoła sprawującym liturgię nakazywało zachowywać ritus servandus, natomiast dzisiaj ars celebrandi.

Natomiast ostatnie pytanie dotyczyło zależności, jaka istnieje między kultem a kulturą. Kult jest rodzajem wyprodukowanej kultury. A co z punktu widzenia społecznego jest dzisiaj produktem kultu?

„Chociaż po II Soborze Watykańskim wiele uczyniono, by odnaleźć autentyczny sens liturgii, to sporo jeszcze pozostało do zrobienia. Konieczna jest stała odnowa i ciągła formacja wszystkich: kapłanów, osób konsekrowanych i świeckich" (Jan Paweł II, Ecclesia in Europa, 72). 


\section{Nowe studia licencjacko-doktoranckie w Instytucie Liturgicznym \\ Wydziału Teologicznego Papieskiej Akademii Teologicznej w Krakowie}

Nowe stacjonarne studia licencjacko-doktoranckie w Instytucie Liturgicznym Wydziału Teologicznego Papieskiej Akademii Teologicznej w Krakowie przeznaczone są dla absolwentów teologii, którzy legitymują się tytułem magistra teologii. Słuchaczami studiów mogą być również absolwenci innych kierunków, którzy zakończą naukę uzyskaniem dyplomu ukończenia.

\section{SPECYFIKA STUDIÓW}

Przedmiotem studiów będzie liturgika porównawcza, czyli liturgia katolicka w kontekście innych liturgii chrześcijańskich i liturgii judaistycznej. W ramach zajęć studenci będą uczestniczyć w liturgii tych wyznań i religii. Niektóre zagadnienia przedstawiane będą komunikacyjnie lub ewangelizacyjnie (komunikacja w liturgii, katechumenat). Szczegółowy program studiów można znaleźć na stronie internetowej: www.pat.krakow.pl.

OPCJE W OBRĘBIE SPECJALIZACJI

- liturgika porównawcza,

- komunikacja w liturgii (homiletyka),

- inicjacja chrześcijańska (katechumenat).

\section{WYKŁADOWCY}

Pracownicy Papieskiej Akademii Teologicznej w Krakowie oraz zaproszeni na zajęcia wykładowcy z innych uczelni oraz z innych wspólnot chrześcijańskich i wspólnoty żydowskiej.

\section{ZGEOSZENIA}

Kandydaci na studia doktoranckie powinni złożyć do 15 września 2008 roku w sekretariacie Instytutu Liturgicznego następujące dokumenty: kwestionariusz osobowy, odpis dyplomu magistra teologii, pisemną zgodę biskupa lub wyższego przełożonego na podjęcie studiów, 4 zdjęcia, kserokopię dowodu osobistego.

\section{ADRES}

Instytut Liturgiczny PAT, 31-123 Kraków, ul. Szujskiego 4, tel. (12) 422 6957; e-mail: il@pat.krakow.pl 